\title{
Perkembangan Moral Pada Anak
}

\author{
Laila Maharani
}

Dosen Fakultas Tarbiyah dan Keguruan, IAIN Raden Intan Lampung

Diterima: Oktober 2014. Disetujui: November 2014. Dipublikasikan: Desember 2014

\begin{abstract}
Abstrak: Penelitian ini bertujuan untuk meninjau perkembangan moral pada anak. Pada sikap dan perilaku moral tersirat nilai-nilai yang dianut berkaitan dengan nilai mengenai sesuatu yang dikatakan baik dan benar, patut, dan seharusnya terjadi. Yang menjadi persoalannya mengapa sikap perkembangan moral pada anak saat ini semakin memprihatinkan. Sebagian besar diteruskan dari generasi ke generasi melalui proses pendidikan seumur hidup. Ada nilai-nilai yang perlu dipertahankan, ada yang diasimilasikan ke arah kemajuan atau perubahan progresif, tetapi ada juga yang berubah atau bergeser karena berbagai faktor yang mempengaruhinya. Model ini diharapkan menjadi satu mekanisme kita sebagai orang tua, guru, maupun masyarakat perlu memahami perkembangan sikap moral agar dapat membantu peserta didik mengembangkan sikap moral yang dikendaki, mendidik peserta didik menjadi anak yang baik, dan bersikap moral secara baik dan benar.
\end{abstract}

Kata Kunci: Potensi, Kecerdasan spiritual, Kebermaknaan dan Kebahagiaan hakiki, SDM berkualitas, Bimbingan, Anak usia dini.

\section{Pendahuluan}

Pengertian Moral, Sikap dan Nilai Moral berasal dari kata latin "mores" yang berarti tata cara, kebiasaan, dan adat. Perilaku sikap moral berarti perilaku yang sesuai dengan kode moral kelompok sosial, yang dikembangakan oleh konsep moral. Yang dimaksud dengan konsep moral ialah peraturan perilaku yang telah menjadi kebiasaan bagi anggota suatu budaya. Konsep moral inilah yang menentukan pola perilaku yang diharapakan dari seluruh anggota kelompok.

Menurut piaget (Sinolungan, 1997), hakikat moralitas adalah kecenderungan menerima dan menaati sistem peraturan. Selanjutnya, kohlberg (Gunarsa, 1985) mengemukakan bahwa aspek moral adalah sesuatu yang tidak dibawa dari lahir, tapi sesuatu yang berkembang dan dapat diperkembangkan/dipelajari.

Disamping perilaku moral ada juga perilaku tak bermoral yaitu perilaku yang tidak sesuai dengan harapan sosial karena sikap tidak setuju dengan standar sosial yang berlaku atau kurang adanya perasaan wajib menyesuaikan diri, serta perilaku amoral atau nonmoral yaitu perilaku yang tidak sesuai dengan harapan sosial karena ketidakacuhan atau pelanggaran terhadap standar kelompok sosial.

Sikap adalah perilaku yang berisi pendapat tentang sesuatu. Dalam sikap positif tersirat sistem nilai yang dipercayai atau diyakini kebenarannya. Nilai adalah suatu yang diyakini, dipercaya, dan dirasakan serta diwujudkan dalam sikap atau perilak. Biasanya, nilai bermuatan pegalaman emosional masa lalu yang mewarnai cita-cita seseorang, kelompok atau masyarakat. Moral merupakan wujud abstrak dari nilai-nilai, dan tampilan secara nyata/kongkret dalam perilaku terbuka yang dapat diamati. Sikap moral muncul dalam praktek moral dengan kategori positif/menerima, netral, atau negatif/menolak.

\section{Metode Penelitian}

Metode penelitian ini dilakukan dengan deskriftif kualitatif, dalam tulisan ini peneliti menggunakan studi pustaka atau menggali data dari Library Research untuk memperkaya khasanah keilmuan bimbingan dan konseling. 


\section{Hasil dan Pembahasan}

Anak yang bersikap positif atau menerima nilai-nilai moral, diekspresiakan dalam perilaku yang bersimpati dalam berinteraksi dengan nilai dan orang disekitarnya, seperti mau menerima, mendukung, peduli, dan berpartisipasi dalam kegiatan kelompok. Sikap moral yang netral diekspresikan dalam perilaku sikap tidak memihak (mendukung atau menolak) terhadap nilai yang ada di masyarakat. Sikap moral yang negatif diekspresikan dalam perilaku menolak yang diwarnai emosi dan sikap negatif seperti kecewa, kesal, marah, benci, bermusuhan, dan menentang, terhadap nilai moral yang ada di masyarakat.

Nilai adalah suatu yang diyakini, dipercayai, dirasakan dan diwujudkan dalam sikap/perilaku.

1. Doktrin dan Dogma

Nilai-nilaimoralyang dihormati masyarakat menjadi pandangan hidup/pedoman umum untuk perilaku tiap warga. Pedoman umum muncul sebagai doktrin/dogma suatu kelompok. Doktrin dari suatu ideologi adalah nilai-nilai berupa pendapat yang lama dikaji, dialami, deterima suatu kelompok serta diperjuangkan untuk diwujudkan dalam masyarakat. Dogma adalah patokan nilai-nilai agama yang dipercaya/diyakini dan diupayakan perwujudannya oleh warganya dalam masyarakat.

2. Sikap dan Kategori Moral

Sikap warga terhadap suatu hal muncul dalam praktek moral dengan kategori positif/ menerima, netral, negatif/ menolak. Manusia bersikap positif terhadap hal yang memberi kepuasan pada pemenuhan kebutuhan juga pencapaian cita-cita sesuai tujuan hidup, sikap positf muncul dalam perilaku asosiatif, akomodatif, integratif dan konstruktif. Juga mungkin bersikap netral yaitu tak mendukung juga tidak menolak. Hal-hal yang mengecewakan menumbuhkan emosi dan sikap negatif. Sikap negatif terwujud dalam perilaku yang mewarnai rasa jengkel, kecewa, benci, marah, atau bermusuhan.

3. Perilaku bermoral dan perubahan

Dalam perilaku bermoral didalamnya terdapat nilai-nilai yang dianut. Ini menunjukkan apa yang baik, benar, patut serta seharusnya terjadi. Jika terjadi peringatan, pembuatan janji, memulai serta maksud membela diri menyatakan penyesalan/ menggambarkan suatu harapan. Sikap moral sebagian besar diteruskan dari generasi ke generasi, penampilan sikap dapat mengalami perubahan sejalan dengan perkembangan kepribadian yang mewarnai perilaku seseorang. Ia aktif dan selektif membentuk sikap untuk berperilaku bermoral dalam lingkungannya. Dalam perkembangan kepribadian seseorang mungkin bersikap mempertahankan nilai-nilai lama (konservatif) mengasimilasai perubahan kearah kemajuan (progresif). Hal-hal ini menjadi prinsip moral selaku pedoman yang mewarnai/ mendominasai perilakunya.

Dalam mempelajari perkembangan sikap moral peserta didik usia sekolah, piaget (sinolungun, 1997) mengemukakan tiga tahap perkembangan moral sesuai dengan kajian pada aturan dalam permainan anak. Piaget membagi pekembangan menjadi 3 fase yaitu:

1. Fase absolut. anak menghayati peraturan sebagai suatu hal yang dapat diubah, karena berasal dari otoritas yang dihormatinya. Disini peraturan sebagai moral adalah obyek eksternal yang tidak boleh diubah.

2. Fase realitas anak menyesuaikan diri untuk menghindari penolakan orang lain. Peraturan dianggap dapat diubah, karena berasal dari perumusan bersama. Mereka menyetujui perubahan yang jujur dan disetujui bersama, serta merasa bertanggung jawab menaatinya. Fase subyektif anak memperhatikan motif/kesengajaan dalam penilaian perilaku. Perkembangan moral dipengaruhi upaya membebaskan diri dari ketergantungan pada orang tua, meningkatkan interaksi dengan sesama dan berkontak dengan pandangan lain. Dengan 
interaksi yang bertambah luas anak makin mampu memahami pandangan orang lain dan berbagi aturan untuk kehidupan bermoral dalam kebersamaan.

Dalam kategori perkembangan moral, kohlberg (gunarsa, 1985) mengemukakan tiga tingkat dengan enam tahap perkembangan moral:

1. Tingkat 1: Prakonvensional

Pada tingkat ini aturan berisi aturan moral yang dibuat berdasarkan otoritas. Anak tidak melanggar aturan moral karena takut ancaman atau hukuman dari otoritas. Tingkat ini dibagi menjadi dua tahap: (1) tahap orientasi terhadap kepatuhan dan hukuman pada tahap ini anak hanya mengetahui bahwa aturan-aturan ini ditentukan oleh adanya kekuasaan yang tidak bisa diganggu gugat. Anak harus menurut, atau kalau tidak, akan mendapat hukuman, (2) tahap relativistik hedonosme pada tahap ini anak tidak lagi secara mutlak tergantung pada aturan yang berada di luar dirinya yang ditentukan orang lain yang memiliki otoritas. Anak mulai sadar bahwa setiap kejadian mempunyai beberapa segi yang bergantung pada kebutuhan (relativisme) dan kesenangan seseorang (hedonisme).

2. Tingkat 2: Konvensional

Pada tingkatan ini anak mematuhi aturan yang dibuat bersama agar diterima dalam kelompoknya. Tingkat ini juga terdiri dari dua tahap: (1) tahap orientasi mengenai anak yang baik. Pada tahap ini anak mulai memperlihatkan orientasi perbuatan yang dapat dinilai baik atau tidak baik oleh orang lain atau masyarakat. Sesuatu dikatakan baik dan benar apabila sikap dan perilakunya dapat diterima oleh orang lain atau masyarakat.

(2)tahap mempertahankan norma sosial dan otoritas. Pada tahap ini anak menunjukkan perbuatan baik dan benar bukan hanya agar dapat diterima oleh lingkungan masyarakat di sekitarnya, tetapi juga bertujuan agar dapat ikut mempertahankan aturan dan norma/ nilai sosial yang ada sebagai kewajiban dan tanggung jawab moral untuk melaksanakan aturan yang ada.

3. Tingkat 3: pasca konvensional

Pada tingkat ini anak mematuhi aturan untuk menghindari hukuman kata hatinya. Tingkat ini juga terdiri dari dua tahap: (1) tahap orientasi terhadap perjanjian antara dirinya dengan lingkungan sosial. Pada tahap ini ada hubungan timbal balik antara dirinya dengan lingkungan sosial dan masyarakat. Seseorang menaati aturan sebagai kewajiban dan tanggung jawab dirinya dalam menjaga keserasian hidup masyarakat; (2) tahap universal. Pada tahap ini selain ada norma pribadi yang bersifat subyektif ada juga norma etik (baik/ buruk, benar/ salah) yang bersifat universal sebagai sumber menentukan sesuatu perbuatan yang berhubungan dengan moralitas.

Teori perkembangan moral yang dikemukakan Kohlberg seperti halnya Piaget menunjukkan bahwa sikap dan perilaku moral bukan hasil sosialisasi atau pelajaran yang diperoleh dari kebiasaan yang berhubungan dengan nilai kebudayaan semata-mata. Tetapi juga terjadi sebagai akibat dari aktivitas spontan yang dipelajari dan berkembang melalui interaksi sosial anak dengan lingkungannya.

Selain teori perkembangan moral, dalam mempelajari pola perkembangan moral yang berkaitan dengan ketaatan akan suatu aturan yang berlaku universal, perlu dibahas mengenai disiplin. Disiplin berasal dari kata disciple yang berarti seseorang yang belajar dari atau secara sukarela mengikuti seorang pemimpin. Disiplin diperlukan untuk membentuk perilaku yang sesuai dengan aturan dan peran yang ditetapkan dalam kelompok budaya tempat orang tersebut menjalani kehidupan. Melalui disiplin, anak belajar untuk bersikap dan berperilaku yang baik seperti yang diharapkan oleh masyarakat lingkungan.

Disiplin dapat ditanamkan secara otoriter melalui pengendalian perilaku dengan menggunakan hubungan. Secara permisif/ laissezfaire melalui kebebasan yang diberikan 
kepada anak tanpa adanya hukuman atau secara demokratis melalui penjelasan, diskusi, dan penalaran mengani peraturan yang berlaku. Menerapkan Pendisiplinan pada Anak: Unsur yang berkaitan dengan disiplin adalah sebagai berikut: Peraturan sebagai pola yang ditetapkan untuk perilaku dimana anak hidup. Mempunyai nilai pendidikan tentang arah yang harus diikuti dan ditaati anak dan juga membantu mengekang perilaku yang tidak diinginkan.

1. Hukuman diberlakukan apabila anak melakukan kesalahan ataupun bertindak yang tidak sesuai dengan nilai/ norma yang berlaku dalam masyarakat. Hukuman yang menghalangi anak untuk tidak mengulangi perbuatan yang tidak diinginkan, mendidik anak untuk belajar dari pengalaman dan memotivasi anak untuk menghindari perilaku yang tidak diterima oleh masyarakat.

2. Penghargaan diberikan apabila anak melakukan sesuatu dengan nilai atau norma yang berlaku, mendidik anak dan memotivasi anak mengulangi perilaku yang baik dan benar sesuai harapan masyarakat.

3. Konsistensi atau keajegan dalam melaksanakan aturan dan disiplin sehingga tidak membingungkan anak dalam memperlajari sesuatu yang benar/ salah, baik/ buruk. Disiplin bermanfaat apabila ada pengaruh disiplin terhadap perilaku, menimbulkan kepekaan akan sikap perilaku yang baik, benar, dan adil serta mempengaruhi kepribadian anak dimanasikapperilakudisiplin merupakan bagian yang terinternalisasi pada anak secara keseluruhan.

Anak dilahirkan tanpa moral (imoral) sikap moral untuk berperilaku sesuai nilai-nilai luhur dalam masyarakat belum dikenalnya. Intervensi terprogram melalui pendidikan, serta lingkungan sosial budaya, mempengaruhi perkembangan struktur kepribadian bermuatan moral. Ini dialami dalam keluarga bersama teman sebaya dan rekan-rekan sependidikan, kawan sekerja/kegiatan ditengah lingkungan. Berikut ini faktor-faktor yang mempegaruhi perkembangan moral:

1. Perubahan dalam lingkungan, Perubahan dan kemajuan dalam berbagai bidang membawa pergeseran nilai moral serta sikap warga masyarakat ditengah perubahan dapat terjadi kemajuan/kemrosotan moral. Perbedaan perilaku moral individu sebagian adalah dampak pengalaman dan pelajaran dari lingkungan nilai masyarakatnya. Lingkungan memberi ganjaran dan hukuman. Ini memacu proses belajar dan perkembangan moral secara berkondisi.

2. Struktur kepribadian, Psiko analisa (Freud) menggambarkan perkembangan kepribadian termasuk moral. Dimulai dengan sistem ID, selaku aspek biologis yang irasional dan tak disadari. Diikuti aspek psikologis yaitu subsistemego yang rasional dan sadar. Kemudian pembentukan superego sebagai aspek sosial yang berisi sistem nilai dan moral masyarakat.

Ketiga subsistem kepribadian tersebut mempengaruhi perkembangan moral dan perilaku individu. Ketidakserasian antara subsistem kepribadian, berakibat seseorang sukar menyesuaikan diri, merasa tak puas dan cemas serta bersikap/berperilaku menyimpang. Sedang keserasian antara subsistem kepribadian dalam perkembangan moral akan berpuncak pada efektifnya kata hati (superego) menampilakan watak/perilaku bermoral seseorang.

Ada sejumlah faktor penting yang mempengaruhi perkembangan moral anak (Hurlock, 1990). (1) Peran hati nurani atau kemampuan untuk mengetahui apa yang benar dan salah apabila anak dihadapkan pada situasi yang memerlukan pengambilan keputusan atas tindakan yang harus dilakukan; (2) Peran rasa bersalah dan rasa malu apabila bersikap dan berperilaku tidak seperti yang diharapkan dan melanggar aturan; (3) Peran interaksi sosial dalam memberik kesepakatan pada anak untuk mempelajari dan menerapkan standart perilaku yang disetujui masyarakat, keluarga, sekolah, dan dalam pergaulan dengan orang lain.

Menurut kohlberg ada 3 tahap perkembangan moral yaitu: (1) Tahap prokonvensional, dimana aturan berisi ukuran moral yang dibuat otoritas pada tahap perkembangan ini anak tidak akan melanggar aturan karena takut ancaman hukuman dari otoritas; (2) Tahap konvensional, 
anak mematuhi aturan yang dibuat bersama, agar ia diterima dalam kelompok sebaya/oleh otoritasnya; (3) Tahap pascakonvensional, anak menaati aturan untuk menghindari hukuman kata hatinya.

Menurut J. Bull perkembangan moral dibagi menjadi 3 yaitu: (1) Tahap anomi, ketidakmampuan moral bayi. Moral bayi barulah suatu potensi yang siap dikembangkan dalam lingkungan; (2) Tahap heteronomi, dimana moral yang berpotensial dipacu berkembang orang lain/otoritas melalui aturan dan kedisiplinan; (3) Tahap sosionomi, dimana moral berkembang ditengah sebaya/dalam masyarakat, mereka lebih menaati aturan kelompok dari pada aturan otoritas; (4) Tahap otonomi, moral yang mengisi dan mengendalikan kata hati serta kemampuan bebasnya untuk berperilaku tanpa tekanan lingkungan.

Sikap dan perilaku moral dapat dipelajari dengan cara berikut: (1) Belajar melalui cob/ ralat (tryal and error). Anak mencoba belajar mengatahui apakah perilakunya sudah memenuhi standart sosial dan persetujuan sosial atau belum. Bila belum, maka anak dapat mencoba lagi sampai suatu ketika secara kebetulan dapat berperilaku sesuai dengan yang diharapkan; (2) Pendidikan langsung yang dilakukan dengan cara anak belajar memberi reaksi tertentu secara tepat dalam situasi tertentu, serta dilakukan dengan cara memenuhi peraturan yang berlaku dalam keluarga, sekolah, maupun masyarakat sekitar; (3) Identifikasi dengan orang yang dikaguminya. Cara ini biasanya dilakukan secara tidak sadar dan tanpa tekanan dari orang lain. Yang penting ada teladan dari orang yang diidentifikasikan untuk ditiru perilakunya.

Pendidikan saat ini umunya mempersiapkan peserta didik memilki banyak pengetahuan, tetapi tidak tahu cara memecahkan masalah tertentu yang dihadapai dalam kehidupan bermasyarakat sehari-hari. Pendidikan lebih mempersiapkan peserta didik untuk menjadi anak yang pandai dan cerdas, tetapi kurang mempersiapkan peserta didik untuk menjadi anak yang baik. Masalah berkenaan dengan baik dan buruk menjadi kajian bidang moral.

Demikian juga dalam mengembangkan aspek moral peserta didik berarti bagaimana cara membantu peserta didik untuk menjadi anak yang baik, yang mengetahui dan berperilaku atau bersikap berbuat baik dan benar. Sikap dan perilaku moral dapat dikembangkan melalui pendidikan dan penanaman nilai/ norma yang dilakukan secara terintegrasi dalam pelajaran maupun kegiatan yang dilakukan anak di keluarga dan sekolah. Pendidikan bukan hanya mempersiapkan anak menjadi manusia cerdas, tetapi juga menjadi manusia yang baik, berbudi luhur, dan berguna bagi orang lain.

Pengembangan moral melalui pendidikan mestinya bukan hanya mengajarkan nilainilai sebagai slogan saja. Hal ini tampak pada moral yang diyakini penganut dan moral budaya yang diterima masyarakat. Proses pendidikan dan pembelajaran moral diteladankan orang tua dan dilakukan secara terpadu (integrated) pada tiap peluang dalam semua kegiatan sekolah. Pendidik mengajarkan keteraturan hidup, disiplin serta melatih dan membiasakan peserta didik bermoral dalam perilaku dan kegiatannya.

Otoritasmendukung berbagai kegiatan pengembangan moral warga masyarakat sebagai bagian upaya membangun karakter manusia indonesia seutuhnya. Cara yang ideal adalah dengan memantapkan pancasila melalui keteladanan pendidik pada umumnya kepada warga bangsa sebagai peserta didik sepanjang hayat dalam proses membangun moral bangsa.

\section{Daftar Pustaka}

Cahyani Ani, Mubin, Psikologi perkembangan cetakan I Quantum Teaching, Ciputat: Press Group, 2006

Hurlock, B Elizabeth, Developmental Psikologi, Mc Grow Hill, Inc, 1980

Istiwidayanti dan Suedjarwo, Psikologi Perkembangan suatu pendekatan sepanjang Rentang Kehidupan, Jakarta, Erlangga, 2002 
Nurihsan, Juntika, Buku Materi Pokok Perkembangan Peserta didik, Bandung: PPs Universitas Pendidikan Indonesia, 2007

Santrock, John W, Life-Span Development, WM, C Brown Comunication, Inc, 1995, Alih bahasa Achmad Chusairi, S.PSI, Perkembangan Masa Hidup Jilid I, Jakarta, Erlangga, 2002.

Suryabrata Sumadi, Psikologi Pendidikan, Jakarta: PT Raja Grafindo, 2004

Yuliani, Sujiono, Bambang, Mencerdaskan Perilaku Anak Usia Dini, Jakarta: Gramedia, 2005

Yusuf, Syamsu, Psikologi Perkembangan Anak dan Remaja, Bandung: Remaja Rosdakarya, 200 